\title{
FILARIAE FROM A WILD GORILLA IN GABON WITH DESCRIPTION OF A NEW SPECIES OF MANSONELLA
}

\author{
BAIN O.*, MOISSON P.**, HUERRE M.***, LANDSOUD-SOUKATE J..** \& TUTIN C.** \\ With the technical assistance of TCHÉPRAKOFF R.*
}

\section{Summary :}

A search for filariae was performed on a wild male Gorilla g. gorilla from the Lopé Reserve in Gabon, which had died as a result of injuries inflicted by another male gorilla. A female worm of Loa loa and female worms of two species of Mansonella were recovered from the deep tissues of a wounded thigh. In order to analyze these Mansonella, specimens of $M$. (E.) perstans, M. (E.) vanhoofi and M. (E.) streptocerca from the Collections of the Museum National d'Histoire Naturelle de Paris have been studied and new important discriminative characters characterised, such as the body-swellings in M. (E.) perstans, due to the presence of coelomocytes as in South-american M. (Tetrapetalonema) spp. One of the Mansonella from this gorilla was not identified, but the body-swellings and the microfilarial morphology suggested a possible similarity with M. (Esslingeria) perstans. The other species is new; M. (E.) lopeensis n. sp. is distinguished by its large size, lack of body-swellings, structure of the tegumental sheath, complex vagina, and a tail with a subterminal constriction, a terminal bend and large lappets.

Histological sections of organs of this gorilla also showed a microfilaria of $M$. (E) leopoldi in the blood vessels of the liver, and a male of Mansonella sp., interestingly situated in an afferent lymphatic vessel of an axillary lymph node.

The diversity of the Mansonella (Esslingeria) species in Africa, compared to the small number of hosts, may have resulted from successive speciations in the hosts, or might be a survival of a parasite fauna diversified at the time of the radiation of the African apes (first half of Miocene).

KEY WORDS : Filariae. Mansonella (Esslingeria). description. lymphatic biology. Anthropoids. Africa.

\section{INTRODUCTION}

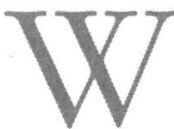

estern lowland gorillas (Gorilla gorilla gorilla Savage et Wyman, 1847) occur in the tropical rain forest of west central Africa and Gabon shelters a significant population (Tutin \& Fernandez, 1984). Research on the ecology and behaviour of lowland gorillas and sympatric chimpanzees (Pan troglodytes troglodytes Blumen-

\footnotetext{
* Laboratoire de Biologie Parasitaire, Protistologie, Helminthologie, CNRS URA-114, Muséum National d'Histoire Naturelle, 61 rue Buffon, F-75231 Paris Cedex 05.

** Centre International de Recherches Médicales de Franceville, BP 769 , Franceville, Gabon.

*** Unité d'Histopathologie, Institut Pasteur, 25 rue du Dr Roux, F-75724 Paris Cedex 15.
}

Résumé : FILAIRES ISOLÉES D'UN GORILLE SAUVAGE DU GABON ET DESCRIPTION D'UNE NOUVELLE ESPĖCE DE MANSONELLA

Une recherche des filaires a été effectuée sur un Gorilla g. gorilla sauvage d'une réserve du Gabon. Une femelle de loa loa et deux espèces de Mansonella, représentées par des femelles, ont été récoltées dans les tissus profonds d'une cuisse endommagée par une morsure. Pour analyser ces Mansonella, des spécimens en collection de M. (E.) perstans, M. (E.) vanhoofi et M. (E.) streptocerca ont été observés et de nouveaux caractères discriminatifs importants précisés : par exemple, mise en évidence chez $M$. (E.) perstans de renflements dans la région antérieure du corps, dûs à la présence de coelomocytes comme chez les M. (Tetrapetalonema) sud-américains. Une des Mansonella de ce gorille n'a pu être identifiée; mais la présence de renflements et la morphologie de la microfilaire suggèrent une similitude possible avec M. (Esslingeria) perstans. L'autre espèce est nouvelle; M. (E.) lopeensis $n$. sp. se distingue par sa grande taille, l'absence de renflements, la structure du fourreau épithélio-musculaire, le vagin complexe, la queve (présence d'une constriction subterminale, extrémité coudée, languettes grandes). Des coupes histologiques d'organes de ce gorille ont permis aussi d'identifier une microfilaire de $M$. (E) leopoldi dans les vaisseaux $d u$ foie et un mâle de Mansonella sp., très intéressant par sa localisation intra-lymphatique (vaisseau afférent d'un ganglion axillaire). La diversité des espèces de Mansonella (Esslingeria) en Afrique, actuellement pauvre en Singes Anthropoïdes, pourrait résulter de spéciations successives chez ces hôtes ou être la survivance d'une faune diversifiée lors de la radiation des hôtes /première moitié du Miocène).

MOTS CLÉS : Filaires. Mansonella (Esslingeria). description. biologie lymphatique. Singes Anthropoïdes. Afrique.

bach, 1779) began in the Lopé Reserve, in central Gabon, in 1983 and is on-going (e. g. Tutin et al., 1991; Williamson et al., 1990). The study area of 50 $\mathrm{km}^{2}$ is isolated and researchers are the only humans present. The area is well protected from hunting and $12 \mathrm{~km}$ from the closest village. The adult male of the main study group of gorillas died in April 1993 as a result of multiple injuries inflicted by another male gorilla. The dead male, named Porthos, had been known to researchers since 1984 and while his exact age was unknown, he was judged to have been between 40-50 years old at the time of his death (Tutin \& Fernandez, 1993). Porthos was observed for five hours on April 22; he was alone and in very poor health. He died during the night and his body was recovered early the next morning and carried to the 


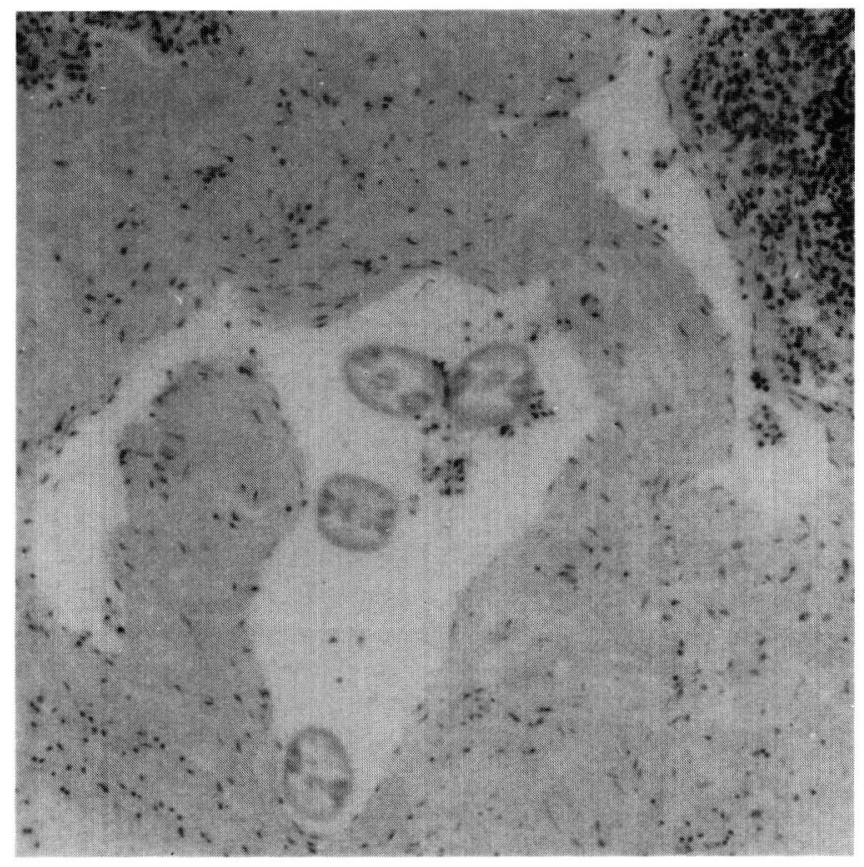

Fig. 1. - Male of Mansonella (Esslingeria) sp. in the afferent lymphatic vessel of the right axillary lymphnode (Scale $20 \mu \mathrm{m}$ ). field station where a necropsy was performed. Tissues were sampled for histopathological analysis and parasites were recovered. The general results have been reported (Moisson et al.,1994 a and b).

Several filarial worms were found in this gorilla, during the examination of the histological sections or during the necropsy (collection number $81 \mathrm{SE}$, MNHN, Paris). The material was fragmentary because these long and thin worms are difficult to extract from the tissues. Nevertheless, the diversity and interest of the recovered material was clear.

\section{LIST OF THE FILARIAE OBSERVED}

\section{During histological examination}

- One male filaria, in transverse and longitudinal sections, was situated in the afferent lymphatic vessel of the right axillary lymphnode (Fig. 1). It was $60-80 \mu \mathrm{m}$ in diameter; the tegumental sheath was characterized by a small number of muscle-cells (4-5 in each submedian quadrant). It seemed possible to assign this worm to the genus Mansonella, which is represented in the African apes (Gorilla gorilla, Pan troglodytes and $P$. paniscus) by several species of the subgenus Esslingeria Chabaud et Bain, 1976 and of which several females were found during Porthos' necropsy. The lymphatic localization of the specimen, already described for other African Mansonella (cf. Rodhain, 1955) reinforces the idea that the filariae of the subfamily Onchocercinae are parasites of the lymphatic system (Bain et al., 1994).

\begin{tabular}{|c|c|c|c|c|c|c|c|c|c|c|}
\hline & streptocerca & rodhaini & \multicolumn{2}{|c|}{ perstans } & gorillae & \multicolumn{3}{|c|}{ vanhoofi } & leopoldi & lopeensis n sp \\
\hline $\mathrm{L}$ & 27 & 25 & 50 & & $47-49.9$ & $56.6-66.7$ & $57-61$ & 64 & $62-63.5$ & 94 \\
\hline W & 81 & 85 & & 110 & 115 & $116-135$ & 100 & 127 & $190-201$ & $200-215$ \\
\hline body swell. & no & no & & present* & no & no & no & no & present & no \\
\hline $\mathrm{nr}$ & 203 & 178 & & $260-280$ & & $286-264$ & 230 & 290 & & 300 \\
\hline oeso & 547 & 522 & & $770-790$ & 710 & $492-503$ & $650^{*}$ & 499 & 855 & 1320 \\
\hline vulva & 517 & 502 & & $770-790$ & 666 & $1142-1186$ & $1350^{*}$ & 1163 & 836 & 2070 \\
\hline ovijector & & & & $>1.5-1.7$ & & & 2250 & & & 2100 \\
\hline tail & 118 & 116 & & $140-170$ & 142 & $135-143$ & 135 & 139 & 216 & $375-400$ \\
\hline L Mf & $190-208^{*}$ & 329 & 196.4 & $162-205^{*}$ & 170.8 & 182.8 & $148-156^{*}$ & 182.5 & 221 & $150-175$ \\
\hline W Mf & $4.5^{*}$ & 2.4 & 4.44 & $2.5^{*}$ & 3.4 & 4.45 & $2^{*}$ & 4.5 & 11 & $3.5-4$ \\
\hline post ext Mf & bifid & round & round & round* & pointed & & pointed* & rounded & enlarged & round \\
\hline
\end{tabular}

Table 1. - African Mansonella (Esslingeria) spp : dimensions of female worms and microfilariae.

Measurements in $\mu \mathrm{m}$ except body length in $\mathrm{mm}$. L, length; $\mathrm{W}$, width; nr, nerve ring; oeso, oesophagus; vulva, distance to head; Mf, microfilaria; post. ext. Mf, shape of the posterior extremity of the microfilaria; ${ }^{*}$, personal data.

Sources of data : - streptocerca, in Peel \& Chardome, 1946 (host Pan paniscus Schwartz, Zaire), Mf from uterus (Human, Zaire, MNHN 91 ED); - rodhaini, in Peel \& Chardome, 1947 (P. troglodytes schbweinfurthi Giglioli, Zaire); - perstans, left column, in Low, 1903 (Human, Tropical Africa); right column in Chabaud, 1952, and Mf from uterus (Human, Congo, 87 B); - gorillae, in Berghe, Chardome \& Peel, 1964 ( $G$. gorilla beringei, Zaire); - vanhoofi, from left to right, original description in Peel \& Chardome, 1946 (P. paniscus, Zaire), in Chabaud \& Rousselot, 1956 and Mf from uterus (P. t. troglodytes Linné, Congo Brazzaville), in Berghe, Chardome \& Peel, 1964 (G. g. beringei, Zaire); leopoldi, in Berghe, Chardome \& Peel, 1964 (G. g. beringei, Zaire); lopeensis n. sp. (G. g. gorilla, Gabon). 


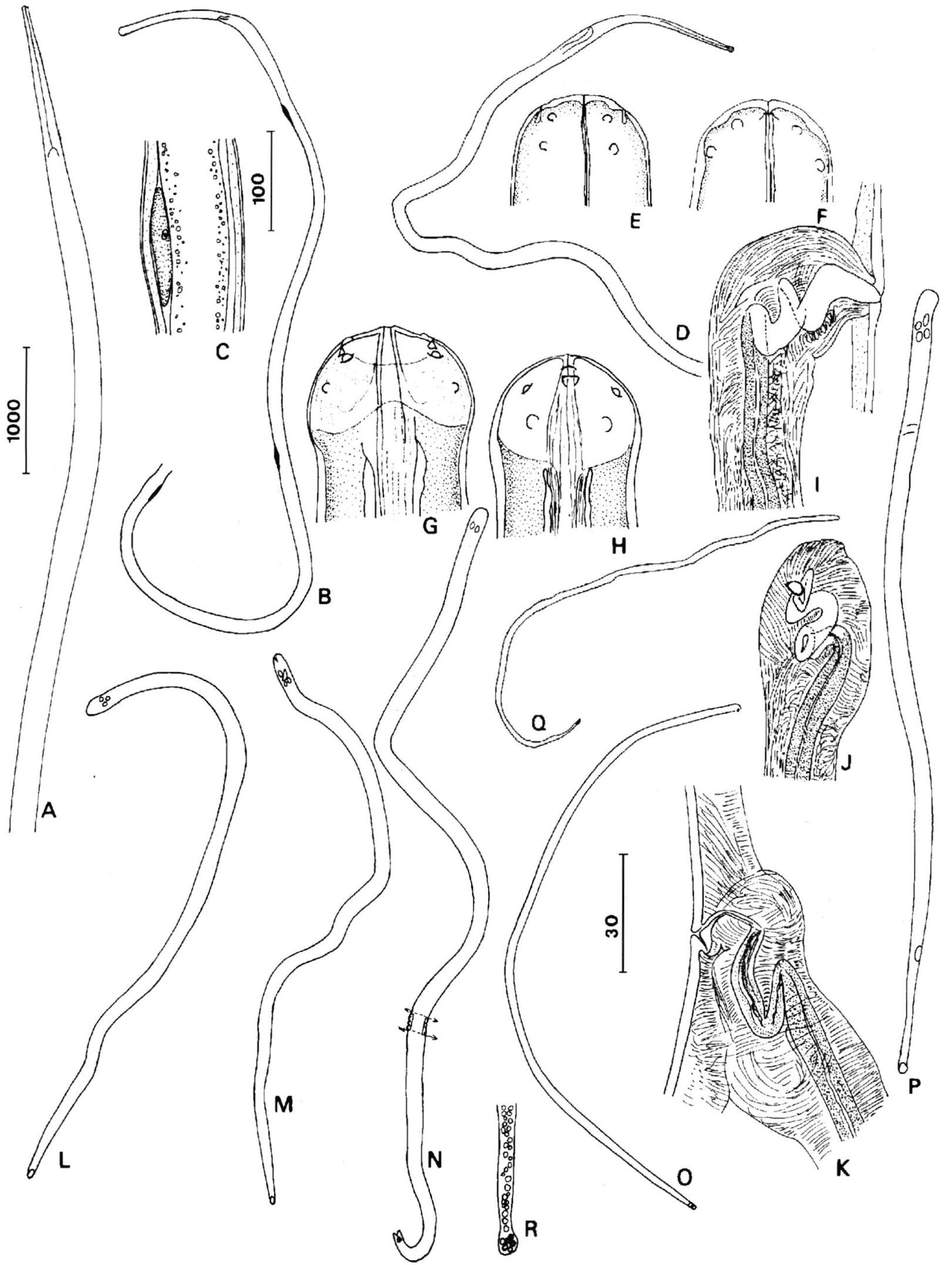

Fig. 2. - A : Silhouette of anterior body of $M$. (E.) lopeensis n. sp; B : idem, $M$. (E.) perstans and C : detail of a swelling with a giant coelomocyte; $\mathrm{D}:$ Anterior silhouette of $M$. (E.) vanhoofi; $\mathrm{E}, \mathrm{F}: M$. (E.) streptocerca, head median and lateral views; G, H: M. (E.) vanhoofi, idem; I, J : M. (E.) streptocerca, vagina, lateral and ventral views; $\mathrm{K}: M$. (E.) vanhoofi, vagina, lateral view; $\mathrm{L}$ to R, microfilariae; $\mathrm{L}$ : from uterus of the perstans -like female from the gorilla Porthos; $\mathrm{M}$ : from the uterus of $M$. (E.) lopeensis $\mathrm{n} . \mathrm{sp}$.; $\mathrm{N}$ : from the uterus of $M$. (E.) streptocerca; $\mathrm{O}$ : from the uterus of $M$. (E.) perstans; P : from the blood of the Gorilla Porthos; Q : from the uterus of $M$. (E.) vanhoofi; $\mathrm{R}$ : caudal extremity of $M$. (E.) leopoldi from an histological section of the liver (Scales in $\mu$ m; A, B, D, 1000; C, 100; others, 30). 
- A microfilaria, its caudal extremity enlarged with several nuclei, was found in a sinusoid vessel of the liver (Fig. 2R). The morphology showed it to be Mansonella (E.) leopoldi (Berghe, Peel et Chardome, 1957), described from Gorilla g. beringei in Zaïre, although its thickness is less probably due to the fixation $(5 \mu \mathrm{m}$ compared to $11 \mu \mathrm{m})$.

\section{During necropsy}

"A small balls of thin worms" were seen during the incision of the femoral artery of one thigh, but this last was damaged by a muscular trauma, so the exact localization of the worms remains imprecise. Three filarial species were present :

- A female of Loa loa (Cobbold, 1864). No blood microfilariae of this species were found. The parasitism of gorillas and chimpanzees by this filaria gave rise to the creation of a new generic taxa (Rodhain \& Berghe, 1939), but it was not justified (Chabaud \& Choquet, 1953); similarly, the creation of a new species (Berghe et al., 1957) has not been supported.

- A female worm, without head and tail, but with microfilariae (collection number MNHN $81 \mathrm{SE}$, a). It presented the following characters : in the anterior part of the body, there were three ventral swellings each with a giant coelomocyte; the transverse section of the body was oval or almost diamond-shaped (depending on the position along the body), and $120 \mu \mathrm{m}-80 \mu \mathrm{m}$ wide, with 9-10 muscle-cells in each quadrant (Fig. 4A, B); uterine microfilariae were wider in the anterior part, 170-180 $\mu \mathrm{m}$ long, 3-3,5 $\mu \mathrm{m}$ wide at mid-body, with a round terminal caudal nucleus (Fig. 2L). With these characters, this specimen showed similarities with $M$. (E.) perstans (Manson, 1891) (see below).

- A complete female worm (holotype) and a female posterior region (paratype) belonging to the subgenus Esslingeria. They cannot be identified to any known species and are described (collection number MNHN 81 SE, b).

\section{DESCRIPTION OF MANSONELLA (E.) LOPEENSIS N. SP.}

Morphology and dimensions are presented in Figs. 2, 3,4 and Table 1. Anterior part of the body progressively enlarged and devoid of swellings. Transversal section of the body rounded; cuticle slightly thickened laterally; muscle-cells numerous (11-14 in each quadrant). Slight postcephalic narrowing. Head papillae arranged into two rectangles stretched laterally with labial and cephalic indices +4 and +5 respectively (see Bain et al., 1986). Oesophagus filiform without a glandular differentiation. Vulva far behind the oesophago-intestinal junction, and presence of a pre-vulvar fold. Vagina vera complex : it begins with a narrow tube directed posteriorly; after two bends, this tube emerges into a large chamber covered with cuticular finely dentate longitudinal ridges; posteriorly, this chamber communicates with a narrow tube (with two bends) which corresponds to the anterior portion of the ovejector (Fig. 3E). Tail of great size, with a constriction situated $30-45 \mu \mathrm{m}$ from the caudal extremity; this tail is almost straight, except its distal extremity which is strongly bent towards the ventral side, with the caudal lappets upright; lateral lappets more developed than the median ones and directed towards the lateral external sides; median lappets close and parallel to the sagittal body plane (Fig. 3F to I). Uterine microfilariae without sheath, wider in the anterior part but slightly attenuated at the apex; caudal extremity not bifid, with a terminal rounded nucleus (Fig. 2M).

\section{DISCUSSION}

7 his material, devoid of males, may appear insufficient to describe a species. In fact, for the filariae, the characters of the females and their microfilariae are numerous and may be sufficient to discriminate a species. Furthermore, it has been possible to examine some species from the MNHN collections in Paris : M. (E.) perstans, $\mathrm{n}^{\circ} 87 \mathrm{~F}$, recovered by $\mathrm{E}$. Brumpt, in Congo, from a woman, studied by Chabaud, in 1952; M. (E.) vanhoofi, $\mathrm{n}^{\circ} 430$ C, recovered by R. Rousselot, in Congo, from Pan troglodytes, studied by Chabaud \& Rousselot, in 1956; M. (E. ) streptocerca, $\mathrm{n}^{\circ} 91 \mathrm{ED}$, recovered by L.O. Lanoie, in Central Republic Africa, from man, in a cutaneous sampling and studied here. These studies were especially useful when comparing the microfilariae (analyzed after extraction from uteri), the structures of the tegumental sheath i. e. cuticle, hypodermis and muscular layer (analyzed on handmade cross-sections, using a razor blade), the morphology of the vagina, the silhouettes of the anterior and posterior parts of the body and the position and shape of the caudal lappets.

Six species of Mansonella have been listed in anthropoids and humans from Africa. Given the difficulty experienced in the recovery of the adult filariae, microfilariae play an important role at the identification.

M. (E.) streptocerca (Macfie et Corson, 1922), first found in humans, is also a parasite of chimpanzee and gorilla. Its female, described by Peel \& Chardome (1946) then by Gardiner et al. (1979), is distinct from our specimens because of its very small size (Table 1 , Fig. 4F); head shape; simple vagina presenting a relatively large lumen but without differentiated chamber (Fig. 2E, F, I, J); small caudal lappets (Fig. 3L, M, N); and the microfilaria with a bifid tail (Fig. 2N). 

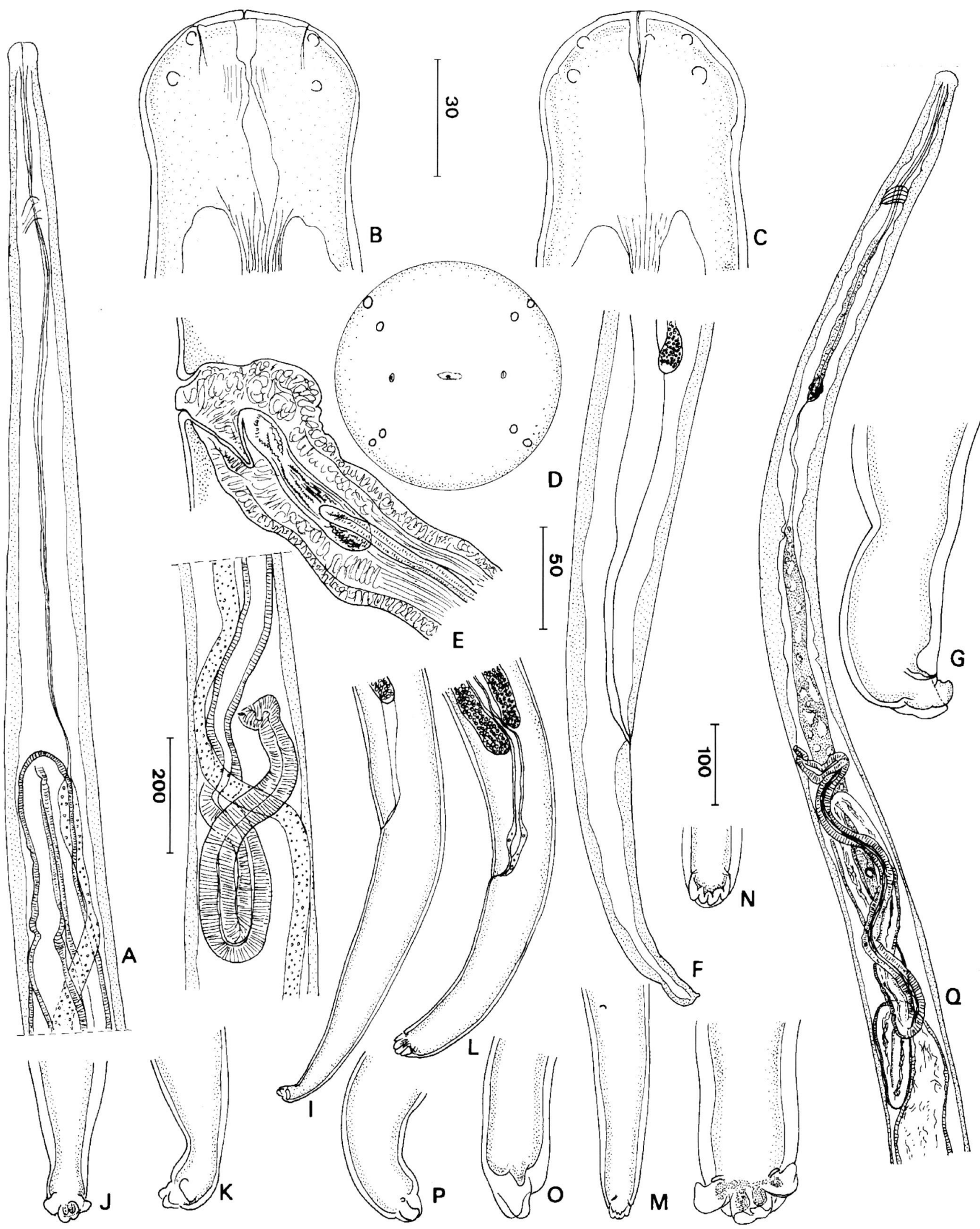

Fig. 3. - A to K, Mansonella (Esslingeria) lopeensis n. sp;. A : anterior region till vulva (drawing in two parts); B, C : head, median and lateral view; D : idem, diagrammatic representation of the apical view; $E$ : vagina; F : tail of the paratype; $G, H$ : idem, caudal extremity, lateral and ventral views; I : tail of the holotype; J, K : idem, caudal extremity,ventral and lateral views. L to N, M. (E.) streptocerca; L, M : tail, lateral and ventral views; $\mathrm{N}$ : idem, caudal extremity, ventral view. O : M. (E.) perstans, caudal extremity, right lateral view; P, Q, $M$. (E.) vanhoofi; P : caudal extremity, right lateral view; Q : anterior region, lateral view (Scales in $\mu \mathrm{m}: \mathrm{A}, 200 ; \mathrm{F}, \mathrm{I}, \mathrm{Q}: 100 ; \mathrm{E}, \mathrm{J}, \mathrm{K}, \mathrm{L}, \mathrm{M}$ : 50; B, C, G, H, N, O, P : 30). 

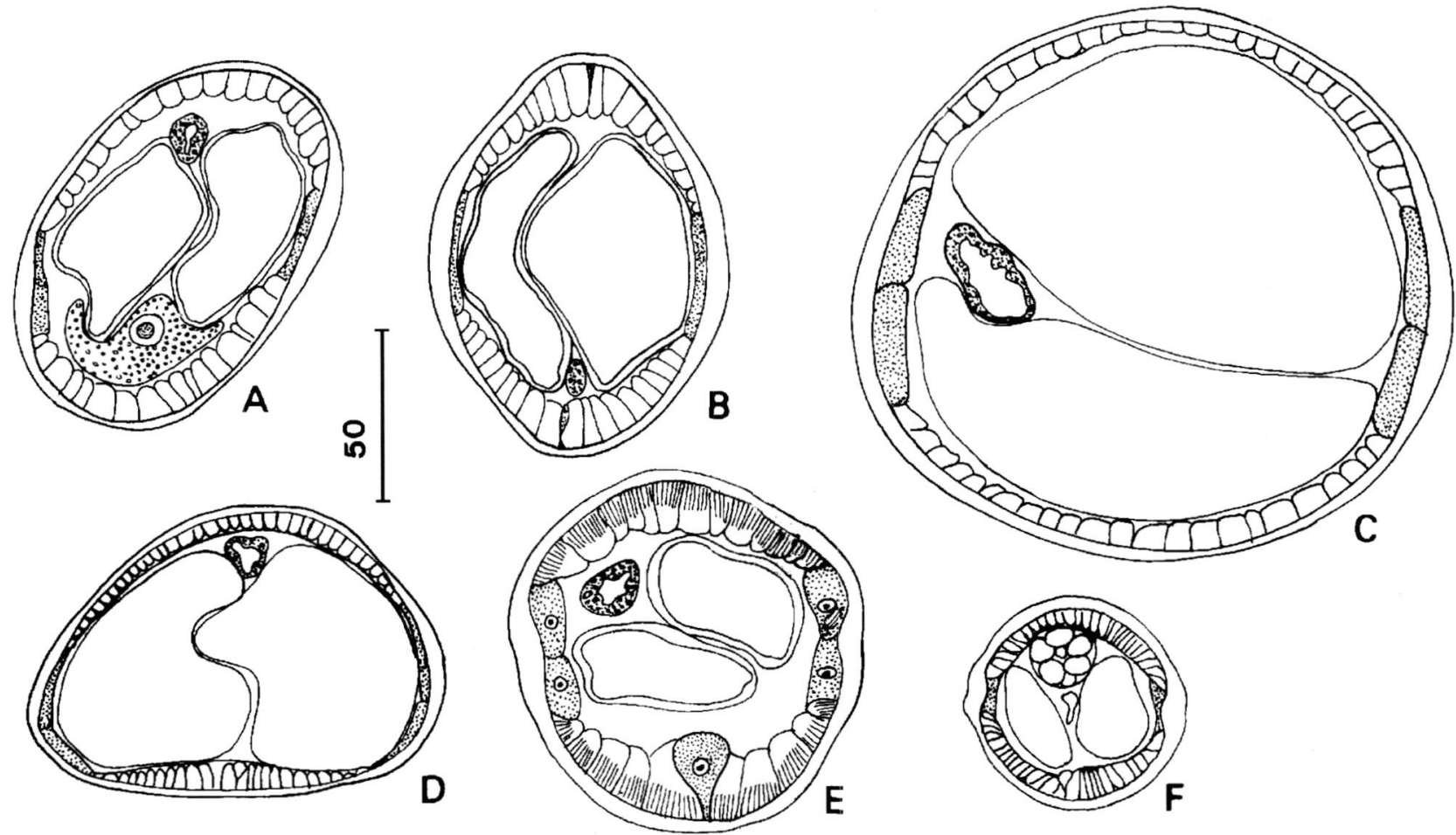

Fig. 4. - Tegumental sheath of female worms in transversal sections; A, B : perstans -like female from the gorilla Porthos; C : M. (E.) lopeensis n. sp.; D : M. (E.) perstans; E : M. (E.) vanhoofi; F:M. (E.) streptocerca (Scale in $\mu \mathrm{m}: 50$ ).

M. (E.) rodhaini (Peel et Chardome, 1946), discovered from the chimpanzee, was found in humans in Gabon (Richard-Lenoble et al., 1982). Its female, described with the male in 1947 by Peel \& Chardome, has very small dimensions; its microfilaria is very long and slender (Table 1).

These first two species have dermal microfilariae; the following species have blood microfilariae, as do our specimens.

$M$. (E.) perstans, common in humans, but also identified in the chimpanzee (in Stiles \& Hassall, 1920). Its microfilaria is very similar to that of our specimens (body wider anteriorly, rounded terminal nucleus, as figured by Fülleborn, 1913, and Vogel, 1928), but it seems to be slightly thinner when the uterine microfilariae are compared. However its female, of which the morphology was described by Chabaud (1952) and completed here, is very different from our specimens. It is shorter and thinner; the shape of its anterior part shows an enlarged head, a slight neck, then a cylindrical shape with almost parallel sides; its transverse section at mid-body is not rounded (Fig. 4D); its tail is curved ventrally at mid length, without a subterminal constriction; the lappets are conical, and in the same plane as the body (i. e. not upright), the lateral ones parallel to the median ones (Fig. 3O). Furthermore, we observed here that the anterior part of the body presents three swellings, with giant coelomocytes, similar to those of Mansonella (Tetrapetalonema) Eberhard et Orihel, 1984 of South-American monkeys (Bain et al., 1986); they are situated at $1,800 \mu \mathrm{m}, 4,700$ $\mu \mathrm{m}$ and $8,000 \mu \mathrm{m}$ from the head, on the measured specimen (Fig. 2B, C). This character, described in Tetrapetalonema berghei Chardome et Peel, 1951, confirms the synonymy of this taxon with $M$. (E.) perstans, as described by Chabaud in 1952 (addendum to the communication on the genus Dipetalonema).

M. (E.) vanhoofi (Peel et Chardome, 1946), discovered in the chimpanzee in Zaire, also parasites the gorilla (Berghe, Chardome \& Peel, 1964). The original description of the adults was completed by Chabaud \& Rousselot (1956), on material from a chimpanzee of the Republic of Congo $\left(n^{\circ} 430 \mathrm{C}\right)$. Despite the existence of a few divergencies between the authors, we base ourselves on the second description and the corresponding museum material for the comparative analysis with our specimens. The uterine microfilaria of $M$. (E.) vanhoof $i$ is thinner and with a more attenuated tail (Fig. 2Q). The oesophagus of the female, which has in fact the dimensions published by Peel \& Chardome, presents a slight glandular differentiation (Fig. 3Q). The vagina is complex but the chamber is not well enlarged. The tail is strongly bent ventrally, with a morphology similar to that of $M$. (E.) perstans; the lappets are small with a rounded apex (Fig. 3P). The transverse section of the body shows muscle-cells 
few in number (5-6 in each quadrant) and a longitudinal groove on the cuticle in the lateral plane (Fig. 4E).

M. (E.) gorillae (Berghe, Chardome et Peel, 1949), first known by the microfilaria (Berghe \& Chardome, 1949) was described from the gorilla and later from the chimpanzee. The microfilaria is distinguished from those of perstans and vanboofi by the absence of a caudal terminal rounded nucleus. It is possible that this character might not be as sure as the authors thought : Rodenwalt (1909), Chardome \& Peel (1951) described perstans microfilariae with an attenuated tail and a last caudal nucleus subterminal and not rounded. The short description of the female does not give characters surely distinct from other species but suffices to differentiate it from our specimens.

M. (E.) leopoldi (Berghe, Peel et Chardome, 1957), known only from the gorilla Gorilla g. beringei in Zaire, differs from our specimens by the thick microfilaria, with a tail as wide as the body presenting two rows of three terminal nuclei. Its female, described in 1964 by Berghe, Chardome \& Peel, with the male, is as wide as our specimens, but differs in several other characters : body less long, presence of four swellings in the anterior part of the body, oesophagus shorter, vulva at the level of the oesophago-intestinal junction, tail without a subterminal constriction and lappets situated as in $M$. (E.) perstans.

Finally, a dermal microfilaria discovered in the chimpanzee and found later in the gorilla, Microfilaria binucleata Peel et Chardome, 1946, of which the adults were seen by Berghe, Chardome \& Peel, in 1957 but not described, is distinct because of the presence of two caudal terminal nuclei.

This analysis shows that the material described here is distinct from the previous species and represents a new species, $M$. (E.) lopeensis n. sp.

The numerous microfilariae found in the blood of the gorilla Porthos present a "perstans" morphology : 145-215 $\mu \mathrm{m}$ long, 5-6 $\mu \mathrm{m}$ wide in the anterior part, a rounded terminal caudal nucleus (Fig. 2P). They are probably a mixture of the two species of Mansonella with mature females found in this ape, $M$. (E.) lopeensis n. sp. and $M$. (Esslingeria) sp. close to $M$. (E.) perstans.

\section{CONCLUSION}

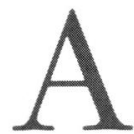

$\mathrm{n}$ analysis of the species of the Mansonella from the anthropoid apes is difficult because descriptions were rarely made all at the same time; more often, the microfilaria was described, then one sex, then the other one, as and when they were collected. Collection is rare due to the mutual sizes of the worms and the hosts which makes their recovery difficult. However, the species described here does not pose any problem of identification because the female is plainly characterized by its great size (94 mm/200-215 $\mu \mathrm{m})$, its shape, its tegumental sheath and its very evolved caudal morphology.

It is not the same for its microfilaria, of which the dimensions are similar to those of $M$. (E.) perstans, $M$. (E.) vanhoofi and $M$. (E.) gorillae. It is unlikely that a differentiation between these four species based on the microfilaria in thick blood films could be done with any certainty.

The diversity of the species of Mansonella in Africa is astonishing compared to the small number of species of hosts, Gorilla gorilla, Pan troglodytes and P. paniscus, and humans. Either these nematodes became diversified by successive speciations in their hosts, a phenomenon which is frequent in the nematodes of vertebrates (Chabaud \& Durette-Desset, 1978), or they are the survival of a parasite fauna which diversified itself at the epoch of the radiation of the African apes, the Panidae, during the first half of the Miocene (Coppens, 1984; Pickford, 1989; Johanson \& Edey, 1983).

\section{ACKNOWLEDGEMENTS}

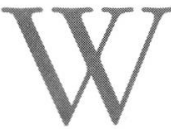

e thank Kate Abernethy, Angelique Diabo Ebatsié, Michel Fernandez, Alphonse Mackanga-Missandzou, Karen McDonald, Ben Voysey, Lee White and the ECOFAC programme (funded by the EU DG VIII and managed by AGREGO-GEIE) for assistance in recovering Porthos' body and in conducting the necropsy at Lopé. Without the support of Alain Georges (Centre International de Recherches Médicales de Franceville) and the cooperation of the Gabonese Presidential Guard, the necropsy could not have been undertaken. Warm thanks go to Brigitte Senut (Laboratoire de Paléontologie-URA 12 CNRS, Muséum National d'Histoire Naturelle, Paris) for her clear explanations of the history of the African anthropoids and for the bibliography that she provided.

\section{REFERENCES}

Bain O., Petit G. \& Rosales-Loesener L. Filaires de Singes sud-américains. Bulletin du Muséum national d'Histoire naturelle, Paris, 4e sér., 1986, 8, sect. A, 513-542.

Bain O., Wanji S., Vuong P. N., Maréchal P., Le Goff L. \& PETIT G. Larval biology of six filariae of the sub-family Onchocercinae in a vertebrate host. Parasite, 1994, 1, 241-254. 
BERGHE L., VAN DEN \& ChARdome M. Une microfilaire du gorille, Microfilaria gorillae. Annales de la Société Belge de Médecine tropicale, 1949, 29, 495-499.

Berghe L., van den, Chardome M. \& Peel E. Dipetalonema gorillae n. sp., filaire de Gorilla gorilla au Congo Belge. Folia Scientif Afr Centr., 1957a, 3, 87.

Berghe L., van den, Chardome M. \& Peel E. Microfilaria leopoldi n. sp. chez Gorilla gorilla au Congo Belge. ibidem, 1957b, 3, 87 .

Berghe L., van den, Chardome M. \& Peel E. Microfilaria binucleata chez Gorilla gorilla au Congo Belge. ibidem, 1957c, 3, 88 .

Berghe L., van den, Chardome M. \& Peel E. Une microfilaire de type loa chez Gorilla gorilla au Congo Belge. ibidem, $1957 \mathrm{~d}, 3,88$.

Berghe L., van den, Chardome M. \& Peel E. The filarial parasites of the eastern gorilla in the Congo. Journal of Helminthology, 1964, 38, 349-368.

Chabaud A.G. Le genre Dipetalonema Diesing 1861; essai de classification. Annales de Parasitologie Humaine et Comparée, 1952, 27, 250-285.

Chabaud A.G. \& Bain O. La lignée Dipetalonema, nouvel essai de classification. Annales de Parasitologie Humaine et Comparée, 1976, 51, 365-397.

Chabaud A. G. \& Choquet M-T. Nouvel essai de classification des filaires (superfamille des Filarioidea). Annales de Parasitologie Humaine et Comparée, 1953, 28, 172-192.

Chabaud A. G. \& Durette-Desset M. C. Parasitisme par plusieurs espèces congénériques. Bulletin de la Société Zoologique de France, 1978, 103, 459-464.

Chabaud A. G. \& Rousselot R. Sur quelques filaires d'Afrique Equatoriale. Annales de Parasitologie Humaine et Comparée, 1956, 31, 53-98.

Chardome M. \& Peel E. Une nouvelle Filaire chez l'homme au Congo Belge : Tetrapetalonema berghei, n. sp. Annales de la Société Belge de Médecine tropicale, 1951, 31, 571-580.

Coppens Y. Hominoïdés, Hominidés et Hommes. La vie des Sciences, Comptes rendus, série générale, 1984, 1, 459486.

EBerhard M. L. \& ORIHel T. C. The genus Mansonella (syn. Tetrapetalonema) : a new classification. Annales de Parasitologie Humaine et Comparée, 1984, 59, 484-496.

FüLlEBORN F. Beiträge zur Morphologie und Differentialdiagnose des Mikrofilarien. Archiv für Schiffs-und Tropenhygiene, 1913, 17, 7-72.

Gardiner C.H., Meyers W.M. \& Lanoie L.O. Recovery of intact male and female Dipetalonema streptocerca from man. American Journal of Tropical Medicine and Hygiene, 1979, 28, 49-52.

JohAnson D. \& EDEY M. Lucy, The beginnings of Humankind. ISBN 0-671-25036-1 Simon \& Schuster, New York, 1983, 442 pp

Low G.C. Filaria perstans. British Medical Journal, 28 Mars 1903, 1-8.

Moisson P., Bain O., Huerre M. \& Tutin C.E.G. Death of a wild lowland gorilla in Lopé reserve, Gabon. XVth
Congress of the International Primatological Society, 3-8 August 1994 a, Kuta-Bali, Indonesia, 1 p.

Moisson P., Bain O., Fiette L. \& Huerre M. Autopsie d'un Gorille sauvage des plaines âgé de 30 ans : insuffisance cardio-respiratoire et parasitoses multiples. XVII ${ }^{e}$ Congrés International des Anatomopathologistes de Langue Française. Bruxelles, 21-23 sept., 1994 b, 1 p.

Peel E. \& Chardome M. Sur des Filaridés de Chimpanzés "Pan paniscus" et "Pan satyrus" au Congo belge. Annales de la Société Belge de Médecine tropicale, 1946, 26, 117-156.

Peel E. \& Chardome M. Note complémentaire sur des filaridés de chimpanzés Pan paniscus et Pan satyrus au Congo belge. Annales de la Société Belge de Médecine tropicale, 1947, 27, 241-250.

PICKFORD M. Pre-hominid diversity and palaezoogeography. Hominidae, Proceedings of the 2nd International Congress of Human Paleontology, Turin, September 28October 3, 1987, Edited by Giacomo Giacobini, 45-52.

Richard-Lenoble D., Kombila M. \& Bain O. Foyer de filariose humaine au Gabon à microfilaire dermique indifférenciable de Microfilaria rodhaini. Annales de Parasitologie Humaine et Comparée, 1982, 57, 506.

Rodenwalt E. Eine neue Mikrofilariae in Blut des Menschen. Archiv für Schiffs-und Tropenbygiene, 1914, 18, 1-12.

Rodhain J. \& Berghe L. van Den. Paraloa anthropopitheci: genre et espèce nouveaux de Filarioidea chez le chimpanzé du Congo belge. Annales de la Société Belge de Médecine tropicale, 1939, 19, 445-452.

RODHAIN J. Au sujet de la localisation de Dipetalonema vanhoofi (Peel et Chardome) chez le Chimpanzé. Bulletin de la Société de Pathologie exotique, 1955, 48, 672-677.

Stiles CH. W. \& Hassall A. Index catalogue of medical and veterinary zoology. Subjects: roundworms. Washington, Government Printing Office, 1920, 886 pp.

Tutin C.E.G. \& Fernandez M. Nationwide census of gorilla (Gorilla g. gorilla) and chimpanzee (Pan t. troglodytes) populations in Gabon. American Journal of Primatology, 1984, 6, 313-336.

Tutin C.E.G. \& Fernandez M. Lowland gorillas in the Lopé Reserve Gabon : A profile of Porthos'group. Gorilla Gazette, 1993, 7, 1-2.

Tutin C.E.G., Fernandez M., Rogers M. E., Williamson E.A. \& MCGREW W.C. Foraging profiles of sympatric lowland gorillas and chimpanzees in the Lopé Reserve, Gabon. Philosophical Transactions of the Royal Society, 1991, Series B, 334, 179-186.

Vogel H. Zur Anatomie der Microfilaria perstans. Archiv für Schiffs- und Tropenhygiene, 1928, 32, 291-306.

Williamson E.A., Tutin C.E.G., Rogers M.E. \& Fernandez M. Composition of the diet of lowland gorillas at Lopé in Gabon. American Journal of Primatology, 1990, 21, 265277. 